
ISSN : 2615-1995, E-ISSN : 2615-0654

J. Madani., Vol. 3, No. 1, Maret 2020 (118 - 131)

(C)2018 Lembaga Kajian Demokrasi

\title{
Analisis Kelayakan Usaha Baby Buncis Kenya Kelompok Tani "Baby French Farmer Group" Dari Aspek IFAS, EFAS, dan IE
}

\author{
Syamruddin \\ Fakultas Ekonomi, Universitas Pamulang \\ dosen01343@unpam.ac.id
}

\begin{abstract}
Abstrak
Tujuan penelitian ini untuk mengetahui sejauh mana kelayakan bisnis baby buncis Kenya yang dikelola oleh Kelompok Tani "Baby French Farmer Group", Khusunya apabila ditinjau dari aspek IFAS, EFAS, dan IE. Adapun metode yang digunakan yaitu deskriptif kualitatif. Sedangkan untuk memperoleh hasil IFAS dan IFAS dilakukan dengan menggunakan analisis kuantitatif. Hasil penelitian menunjukkan bahwa secara internal berada pada tingkat yang kuat. Begitu pula secara eksternal berada pada tingkat yang tinggi. Dengan demikian kondisi usaha Kelompok Tani "Baby French Farmer Group" berada pada tahap yang tumbuh dan membangun. Adapun simpulan penelitian yaitu usaha baby buncis Kenya oleh Kelompok Tani "Baby French Farmer Group" layak untuk dijalankan dan terus dilanjutkan. Sebab IE Matriks menunjukkan posisi growth and build atau tumbuh dan membangun. Konsentrasi melalui integrasi vertikal.
\end{abstract}

Kata Kunci : SWOT, IFAS, EFAS, IE Matrix

\begin{abstract}
The purpose of this study was to determine the extent of the feasibility of the Kenyan baby bean business managed by the "Baby French Farmer Group" Farmer Group, especially when viewed from IFAS, EFAS and IE aspects. The method used is descriptive qualitative. Whereas to obtain IFAS and IFAS results, it is carried out using quantitative analysis. The results showed that internally was at a strong level. Likewise externally it is at a high level. Thus the business conditions of the "Baby French Farmer Group" Farmer Group are at a stage of growth and development. The research conclusion is that the Kenyan baby bean business by the "Baby French Farmer Group" Farmer Group is feasible to be carried out and continued. Because IE Matrix shows the position of growth and build. Concentration through vertical integration.
\end{abstract}

Keywords : SWOT, IFAS, EFAS, IE Matrix

\section{PENDAHULUAN}

Sektor pertanian masih menjadi salah satu andalan bagi masyarakat di Tanah Air dalam upaya meningkatkan taraf kehidupan ekonominya. Apalagi Indonesia yang merupakan negara agraris memiliki lahan pertanian yang sangat luas. Seperti halnya yang ada di Kabupaten Bandung Barat, di mana para petani yang berada di daerah sejuk itu banyak yang melakukan usaha budi daya baby buncis. Karena mereka meyakini bahwa usaha baby buncis memiliki prospek yang sangat bagus.

Baby buncis merupakan salah satu komoditas yang sangat menjanjikan bagi petani-petani yang ada di daerah Bandung Barat. Untuk itulah sebuah kelompok tani bernama "Baby French Farmer Group" membentuk sebuah paguyuban guna menaungi beberapa kelompok usaha tani dalam 
mengembangkan budi daya tanaman ini menjadi komoditas ekspor. Bahkan, telah menjalin kerja sama dengan berbagai eksportir dan super market dalam memasarkan dan menjual produknya.

Kelompok Tani "Baby French Farmer Group" awal mula pendiriannya diinisiasi oleh Ulus Pirmawan, seorang tokoh pemuda tani yang berdomisili di Kampung Gandok, Desa Suntenjaya, Cibodas, Lembang, Kabupaten Bandung Barat. Dengan kepekaan naluri petani yang didapatnya secara otodidak dan turun-temurun dari orang tuanya sejak usia 12 tahun setelah lulus Sekolah Dasar (SD), maka tak sulit baginya untuk memulai usaha ini. Apalagi ia sudah mulai ikut bertani dengan orang tuanya sejak muda, sehingga tidak sulit baginya untuk mengolah lahan pertanian baby buncis. Selain itu tempat tinggalnya yang sangat ideal untuk lahan pertanian sehingga membuat banyak bandar sayuran yang mengambil komoditas sayuran di daerah tersebut.

Sejak Baby French Farmer Group didirikan pada kurun waktu 2009-2010, ekspor baby buncis para petani di Kampung Gandok setiap harinya lebih dari $300 \mathrm{Kg}$. Hal ini tentu sangat menggembirakan bagi para petani setempat. Sebab usaha yang mereka tekuni selama ini mendapat pasar yang sangat positif. Produk baby buncis mereka tidak hanya dipasok di dalam negeri namun juga sudah menjadi komoditas ekspor ke manca negara.

Karena begitu majunya usaha baby buncis ini tak ayal pula mendapat perhatian dari berbagai pihak. Dalam penelitian terdahulu menunjukkan bahwa dari segi pengembangan kualitas produk usaha Baby French Farmer Group selalu mengikuti perkembangan Standar Operasional Prosedur (SOP) agar tanaman baby buncis yang dihasilkan sesuai dengan kualitas yang diminta konsumen. Misalnya, adanya kerja sama dengan Lembaga Penelitian dan Pengabdian Kepada Masyarakat Universitas Padjajaran (LPPM Unpad).

Selain itu tentunya strategi yang diterapkan oleh Ulus dan kawan-kawan dalam membangun bisnis Baby French Farmer Group juga sangat penting. Karena tanpa strategi bisnis yang tepat tidak mungkin proses bisnis bisa berjalan dengan baik. Dengan strategi bisnis yang tepat telah membuat
Baby French Farmer Group mampu bertahan sampai sekarang.

Strategi bisnis yang diterapkan oleh Baby French Farmer Group pun tidak terlalu rumit. Mereka menggunakan Analisis SWOT dalam strategi bisnisnya. Dengan strategi ini akan diketahui faktor lingkungan internal dan faktor lingkungan eksternal bisnis.

SWOT adalah metode perencanaan strategis yang digunakan untuk mengevaluasi kekuatan (strenghts), kelemahan (weaknesses), peluang (opportunities), dan ancaman (threats) dalam suatu proyek atau suatu spekulasi bisnis. Keempat faktor tersebutlah yang membentuk akronim SWOT (strenghts, weaknesses, opportunities, threats). SWOT akan lebih baik apabila dibahas dengan menggunakan tabel yang dibuat dalam kertas besar. Dengan demikian dapat dianalisis dengan baik hubungan dari setiap aspek.

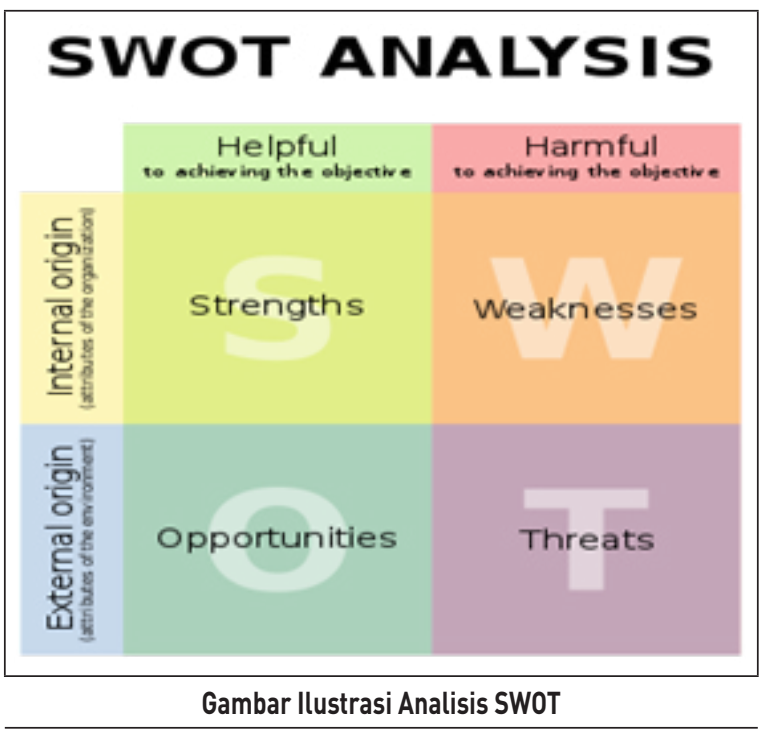

Proses SWOT melibatkan penentuan tujuan yang spesifik dari spekulasi bisnis atau proyek dan mengidentifikasi faktor internal dan eksternal yang mendukung dan yang tidak dalam mencapai tujuan tersebut. Analisis SWOT dapat diterapkan dengan cara menganalisis dan memilah berbagai hal yang mempengaruhi keempat faktornya, yang kemudian menerapkannya dalam Matriks Analisis SWOT.

Matriks SWOT merupakan matriks yang membantu para manajer dalam mengembangkan empat jenis strategi, yaitu strategi SO (kekuatanpeluang), strategi WO (kelemahan-peluang), 
strategi ST (kekuatan-ancaman) dan strategi WT (kelemahan-ancaman). Strategi SO memanfaatkan kekuatan internal perusahaan untuk mendapatkan keuntungan atau kekuatan dari peluang eksternal. Strategi WO bertujuan untuk memperbaiki kelemahan dengan menangkap peluang eksternal yang ada. Strategi ST dilakukan untuk menghindari atau meminimalisir dampak dari ancaman eksternal dengan kekuatan yang dimiliki. Strategi WT merupakan strategi protektif atau defensif untuk melindungi kelemahan yang ada dari ancaman yang mungkin akan merugikan. (Kotler dan Keller, 2009)

Kemudian setelah dilakukan proses melalui Matriks Analisis SWOT, selanjutnyan proses Analisis Internal Factors Analysis Summary (IFAS) dan External Factors Analysis Summary (EFAS). IFAS merupakan kesimpulan analisis dari berbagai faktor internal yang mempengaruhi keberlangsungan perusahaan. EFAS merupakan kesimpulan analisis dari berbagai faktor eksternal yang mempengaruhi keberlangsungan perusahaan.

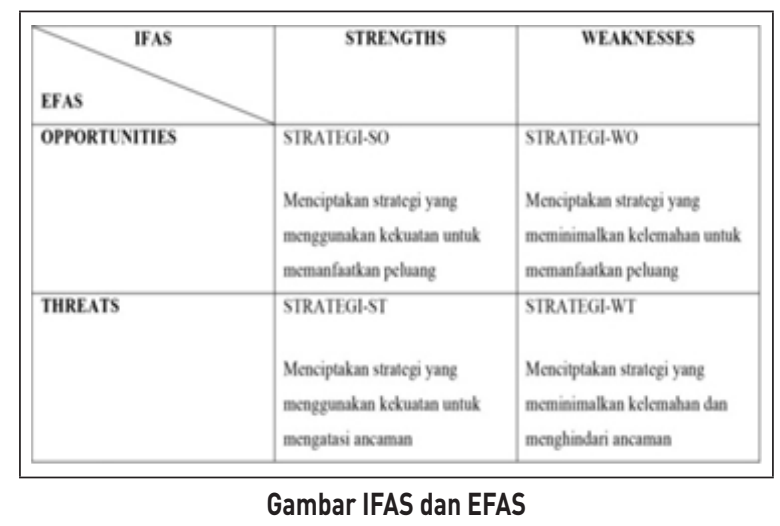

Setelah itu dilakukan evaluasi terhadap faktorfaktor internal perusahaan berkaitan dengan dengan kekuatan dan kelemahan serta peluang dan ancaman. Yaitu dengan menggunakan Matriks Internal Factors Evaluation (IFE) dan Matriks External Factors Evaluation (EFE).

Seperti yang disarikan dari Wiranthi (2011), tahap identifikasi yang dilakukan dengan cara memilih faktor strategis bagi perusahaan dalam bentuk Matriks IFE dan EFE yang bertujuan untuk mengetahui apakah kekuatan yang dimiliki lebih besar dari kelemahan atau sebaliknya. Kemudian apakah perusahaan mampu memanfaatkan pe- luang untuk mengatasi ancaman yang ada.

Tahap berikutnya adalah Analisis Matriks Internal-External (IE), yang merupakan matriks portofolio yang memposisikan perusahaan dalam tampilan sembilan sel. Posisi suatu perusahaan dalam Matriks IE ditentukan dari Matriks EFE dan Matriks IFE. Hasil skor total dari Matriks IFE berada pada sumbu $\mathrm{x}$ dan hasil skor total dari Matriks EFE berada pada sumbu y.

Matriks IE merupakan langkah untuk menentukan posisi strategi bisnis unit ke dalam matriks yang terdiri dari sembilan sel (kuadran). Input dari Matriks IE adalah output dari Matriks IFE dan EFE. Output dari Matriks IE adalah alternatif strategi berdasarkan posisi strategi perusahaan setelah dipetakan ke dalam matriks, di mana terdapat tiga area dengan alternatif strategi yang berbeda. Kuadran I, II, dan IV akan menghasilkan alternatif strategi tumbuh dan berkembang. Kuadran III, V, dan VII akan menghasilkan strategi pertahankan dan pelihara, dan terakhir Kuadran VI, VIII, dan IX akan menghasilkan strategi panen dan divestasi (David, 2009).

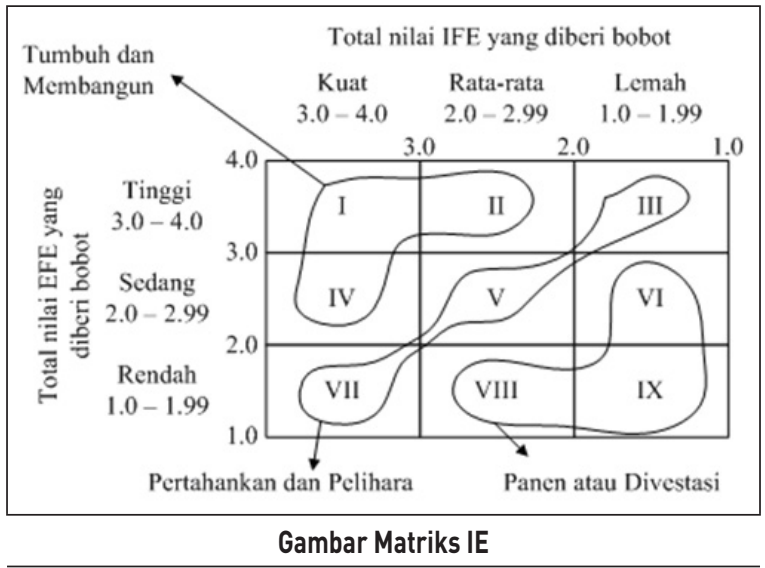

\section{METODE}

Metode yang digunakan dalam penelitian ini adalah deskriptif kualitatif. Metode pengumpulan data terdiri dari observasi, wawancara, dan studi pustaka. Metode pengolahan dan analisis data menggunakan pendekatan konsep manajemen strategis yang terdiri dari analisis kualitatif dan kuantitatif.

Analisis kualitatif digunakan untuk mengetahui kekuatan, kelemahan, peluang, dan ancaman yang dihadapi Kelompok Tani "Baby French Farmer Group". Analisis kuantitatif digunakan 
untuk memperoleh strategi dan prioritas alternatif strategi pada Matriks IFE dan Matriks EFE. Selanjutnya untuk mengetahui kondisi usaha sesuai dengan Matriks IE (IE Matrix).

\section{HASIL dan PEMBAHASAN}

\section{Hasil}

\section{Faktor Lingkungan Internal dan Eksternal}

Berdasarkan hasil wawancara dengan Kelompok Tani "Baby French Farmer Group", yang memberikan pendapat dan penilaian terhadap faktor-faktor internal dan eksternal di dalam organisasi, maka diperoleh data-data yang menunjukkan kondisi operasional.

Adapun faktor-faktor internal di dalam organisasi sebagai berikut :

\section{Faktor Kekuatan Internal}

1. Koordinasi yang baik dari Ketua Gapoktan selaku pimpinan dengan anggota

Koordinasi yang baik antara pimpinan organisasi atau kelompok dengan para petani baik secara formal dan informal. Hal itu dilakukan melalui diskusi, penyampaian informasi, maupun membiasakan petani dalam melakukan komunikasi dan koordinasi yang birokratis dan fungsional.

2. Kecepatan proses pengambilan keputusan Cepatnya proses pengambilan keputusan dalam usaha Baby French Farmer Group terjadi salah satunya dikarenakan Ulus merupakan seorang petani yang memiliki kemampuan di bidang pertanian yang mumpuni. Kemudian karena kemampuan leadership yang baik sehingga mampu membawa suasana kerja yang baik pula pada usaha Baby French Farmer Group. Para petani pada usaha Baby French Farmer Group memiliki sifat proaktif dan solutif sehingga memudahkan Ulus dan tim pengambil keputusan dalam menentukan langkah yang akan diambil dalam waktu yang cepat. Strategi bisnis dilakukan sesuai dengan Rencana dan Anggaran Belanja (RAB) pada setiap satu musim tanam. Jika di antara musim tanam tersebut terdapat permasalahan yang tidak terlalu besar maka akan segera dipecahkan oleh tim pengambil keputusan pada saat itu.

3. Kestabilan dan profitabilitas harga jual baby buncis

Upaya menjaga kualitas dan kepercayaan konsumen baby buncis pada usaha Baby French Farmer Group telah berimbas baik pada kestabilan penjualan dan keuntungan yang diperoleh. Usaha Baby French Farmer Group selalu mencoba untuk memberikan kualitas yang sesuai dengan harga yang diinginkan konsumen. Secara jangka panjang, keuntungan yang ditawarkan melalui budi daya baby buncis ini lebih stabil dan profitable bagi petani. Kadangkala keuntungan yang ditawarkan oleh penjualan buncis lokal pada saat harga sedang melambung tinggi di pasaran dapat membuat petani berpikiran untuk berpindah haluan. Namun demikian hal itu dapat dihindari dengan keuntungan penjualan baby buncis Kenya yang lebih stabil dan memberikan keuntungan dalam jangka waktu panjang.

4. Lokasi usaha yang strategis

Lokasi dari suatu usaha mampu menentukan berjalannya suatu bisnis. Lokasi usaha Baby French Farmer Group sangat strategis di mana berada di perbatasan antara daerah Lembang dan daerah Dago. Sehingga akses menuju pasar terbilang sangat baik karena didukung oleh infrastruktur jalan yang sudah sangat bagus. Banyaknya sesama petani di kawasan ini mampu menciptakan suasana lingkungan usaha yang baik. Untuk mencapai pusat kota dengan menggunakan kendaraan bermotor dapat diakses hanya dalam waktu kurang lebih 30 menit. Hal ini membuat kegiatan distribusi barang menjadi lebih mudah dan hemat waktu. Lokasi yang strategis ini juga memungkinkan transaksi perdagangan lebih mudah untuk dilakukan karena perusahaan eksportir bisa datang sendiri dan melihat lokasi budi daya tanaman baby buncis sebelum akhirnya menentukan untuk bekerjasama dan menjadi mitra bisnis.

5. Optimalisasi penggunaan lahan pertanian Para petani pada usaha Baby French Farmer Group sudah melakukan optimalisasi pro- 
duksi dengan mengelola biaya yang dikeluarkan untuk proses budi daya menjadi lebih hemat. Mereka menggunakan sistem tumpang sari dan penanaman dengan penjadwalan yang baik. Biaya operasional untuk satu jenis komoditas dalam satu kali musim tanam untuk satu hektare lahan pada umumnya membutuhkan biaya sebesar Rp.65.000.000,- hingga Rp.70.000.000,-. Akan tetapi dengan menggunakan sistem penanaman tumpang sari dengan cara mengkombinasikan komoditas yang berbeda dapat menekan pengeluaran pengolahan lahan hingga Rp.45.000.000,-. Selain menekan biaya, dengan melakukan tumpang sari juga dapat menekan kerugian. Sementara dengan melakukan penjadwalan penanaman yang baik akan menekan risiko dan memudahkan petani untuk mengetahui umur tanaman yang layak panen.

6. Ketersediaan sarana produksi

Proses budi daya pada usaha Baby French Farmer Group dapat berjalan dengan baik tentunya dengan menggunakan sejumlah peralatan yang diperlukan. Mulai dari cangkul untuk mempersiapkan lahan hingga keranjang untuk mengangkut hasil panen dari lahan pertanian ke gudang sebelum akhirnya dikirim ke perusahaan eksportir. Ketersediaan peralatan budi daya usaha Baby French Farmer Group terbilang mudah dipenuhi karena tidak membutuhkan peralatan atau mesin canggih yang sulit didapat. Segala kebutuhan budi daya mudah untuk diakses dan diperoleh. Karena teknologi yang digunakan masih termasuk sederhana sehingga petani mudah untuk memenuhi kebutuhan operasional budi daya pada saat proses penanaman baby buncis dilakukan pada setiap musim tanam.

7. Kontrol rantai pasok yang baik

Suatu usaha memerlukan perencanaan dan kontrol rantai pasok yang baik untuk menjamin berjalannya suatu proses bisnis yang dilakukan oleh usaha Baby French Farmer Group. Dengan memanfaatkan ilmu yang didapat dari lingkungan eksternal (VCC), usaha ini mampu mendapatkan informasi yang up to date dari supplier, sesama petani, dan sesama pelaku usaha di lingkungan bisnis yang ada. Hal ini dilakukan oleh usaha Baby French Farmer Group dengan tujuan membuat usaha agar menjadi lebih suistainable dan well-controlled. Selain itu juga memastikan hubungan yang baik dengan supplier, sesama petani, dan mitra bisnis yang akan diajak untuk melakukan kerja sama dengan usaha Baby French Farmer Group.

8. Kemerataan informasi dalam struktur organisasi

Terdapat banyak sumber informasi yang berasal baik dari lingkungan eksternal maupun lingkungan internal yang dapat memberi manfaat kepada usaha Baby French Farmer Group. Apabila terdapat suatu informasi yang penting dan bermanfaat dari lingkungan internal, maka informan akan segera memberi tahu kepada Ketua Gapoktan dan informasi tersebut akan disebarkan secara merata ke seluruh karyawan dan anggota poktan. Begitu pula apabila Ketua Gapoktan memperoleh informasi yang bermanfaat dari lingkungan eksternal maka akan dengan segera informasi tersebut disalurkan secara merata ke seluruh karyawan dan anggota poktan.

\section{Faktor Kelemahan Internal}

1. Keterbatasan upaya mencapai kegiatan promosi yang efektif dan efisien

Adanya kegiatan promosi diharapkan mampu meningkatkan penjualan usaha Baby French Farmer Group. Namun, sejauh ini kegiatan promosi yang dilakukan oleh usaha Baby French Farmer Group belum mampu memberikan perubahan positif yang terlihat signifikan. Hal ini terjadi karena usaha Baby French Farmer Group hanya melakukan promosi sebatas mengikuti pameran maupun bazar yang diadakan oleh pemerintah. Kegiatan tersebut belum mampu menaikkan angka penjualan secara signifikan. Website yang dimiliki oleh usaha Baby French Farmer Group juga belum mampu menarik pelanggan 
baru untuk melakukan kerja sama dengan usaha Baby French Farmer Group. Pemilik sudah mulai memikirkan bentuk promosi yang lain dengan cara berjualan menggunakan mobil dan berkeliling di perumahan sekitar untuk menjemput pasar sekaligus memperkenalkan kualitas dari tanaman baby buncis yang diproduksi. Akan tetapi hal itu belum mampu terlaksana karena perusahaan belum membuat anggaran khusus untuk meningkatkan promosi. Apabila perusahaan melakukan rancangan anggaran dana promosi dengan baik dan merancang dengan jelas kegunaannya, maka tentu akan sangat membantu perusahaan dalam upaya meningkatkan penjualan perusahaan.

2. Penanganan produk reject yang belum optimal

Salah satu faktor vital dalam usaha onfarm adalah risiko produk reject yang tidak mampu dijual ke suatu pasar tertentu. Walaupun perusahaan telah melakukan sistem sortasi dan grading yang baik, namun produk reject yang ditolak oleh mitra bisnis karena dianggap tidak sesuai dengan kualitas yang diinginkan selalu ada. Kuantitas produk reject dapat mencapai $20 \%$ dalam setiap penjualan. Apabila hal ini terjadi maka produk reject hanya dapat dibawa kembali ke gudang, sebagian lagi dijual ke pasar tradisional dan sebagian lainnya hanya dijadikan pakan ternak untuk masyarakat sekitar. Hal ini dikarenakan produk reject sudah mengalami penurunan kualitas pada saat dibawa kembali menuju gudang sehingga tidak dapat dijual lagi $100 \%$. Pemilik perusahaan dan petani yang tergabung dalam usaha Baby French Farmer Group sangat mengharapkan adanya bantuan pemerintah dalam bentuk teknologi yang dapat mengolah produk reject menjadi produk yang bernilai tambah dan dapat dijual dengan harga yang pantas dan masuk akal.

3. Keterbatasan menemukan sumber keuangan yang stabil dan terpercaya

Kegiatan budi daya baby buncis tentunya memerlukan biaya yang besar. Bahkan apabila dihitung dapat mencapai Rp.85.000.000,untuk dua komoditas dalam satu kali masa tanam untuk satu hektare lahan pertanian tumpang sari. Sumber keuangan yang stabil dan dapat dipercaya tentu akan sangat membantu kegiatan budi daya usaha Baby French Farmer Group. Namun sejauh ini usaha Baby French Farmer Group lebih sering menggunakan sumber keuangan pribadi untuk bertani. Sebab menurut para petani sangat sulit mendapatkan pinjaman dari lembaga keuangan karena usaha onfarm dianggap sangat berisiko dan memiliki pengembalian yang kecil. Anggapan ini sudah sangat melekat di kalangan umum sehingga banyak lembaga keuangan yang tidak mempercayakan pinjaman kepada petani yang melakukan usaha onfarm. Padahal jika ada investor yang tertarik untuk menanamkan modalnya pada usaha Baby French Farmer Group, maka bisnis ini akan prospektif dan dengan cepat memberikan keuntungan sejalan makin tingginya minat konsumen baby buncis saat ini dan di masa mendatang. Hal itulah yang menjadi alasan bagi usaha Baby French Farmer Group untuk segera menemukan sumber pemberi modal budi daya yang stabil dan dapat dipercaya.

4. Arus pembayaran yang tersendat

Kondisi yang terjadi pada usaha Baby French Farmer Group saat ini di mana perusahaan eksportir dan mitra bisnis melakukan pembayaran kredit secara berkala kepada usaha Baby French Farmer Group. Sementara petani harus membayar segala bentuk keperluan operasional budi daya dalam bentuk tunai. Selain itu ditambah lagi mitra supermarket yang terkadang terlambat membayar hasil penjualan tanaman baby buncis ke usaha Baby French Farmer Group semakin memaksa petani untuk menggunakan keuangan milik pribadi. Akibatnya membuat petani harus selalu memiliki kas lancar untuk melakukan kegiatan budi daya. Padahal pihak supermarket kerap menuntut produk yang diberikan petani harus diantar dalam frekuensi dua hari sekali di luar hari 
penjemputan hasil penjualan. Hal ini tentunya juga akan menambah biaya transportasi dari petani karena harus mengantarkan tanaman baby buncis ke supermaket. Fenomena inilah yang membuat pemilik perusahaan ingin menerapkan sistem pembayaran yang jelas ke mitra bisnis agar arus pembayaran dan keuangan yang terdapat di dalam usaha Baby French Farmer Group berjalan dengan lancar.

5. Lahan pertanian yang terbatas

Lahan pertanian merupakan jantung dari kegiatan budi daya tanaman baby buncis pada usaha Baby French Farmer Group. Hal ini dikarenakan para petani memiliki keterbatasan sebab tidak lagi dapat memperluas lahan pertanian yang dimilikinya. Penyebabnya antara lain banyaknya pengalihan fungsi lahan dari bentuk penjualan lahan hingga sistem waris. Kondisi ini membuat petani yang tergabung dalam usaha Baby French Farmer Group perlu melakukan intensifikasi lahan yang baik dengan menerapkan teknologi tanam yang baik. Selain itu dengan menambah jumlah tenaga kerja untuk mempercepat rotasi proses budi daya tanaman baby buncis.

Sedangkan faktor-faktor eskternal di dalam organisasi sebagai berikut :

\section{Faktor Peluang Eksternal}

1. Permintaan baby buncis oleh konsumen yang tinggi

Tanaman baby buncis sangat digemari oleh masyarakat karena gizi yang terkandung di dalamnya begitu banyak. Ditambah lagi rasanya yang manis dan renyah dapat menambah selera makan sayuran pada anakanak. Salah satu segmentasi usaha Baby French Farmer Group adalah keluarga menengah ke atas yang mengkonsumsi sayuran secara terus-menerus baik bagi dewasa maupun anak-anak. Tanaman baby buncis juga sering digunakan sebagai teman makan menu masakan western seperti steak bersama wortel dan kentang serta kacang polong. Hal ini juga secara tidak langsung meningkatkan level penjualan tanaman baby buncis men- jadi pasar milik masyarakat menengah ke atas. Selain itu tanaman baby buncis yang dihasilkan di Baby French Farmer Group yang sudah mencapai pasar internasional di Singapura tentunya turut berperan pada penjualan baby buncis. Permintaan baby buncis per hari mencapai 5 Ton. Menurut pemilik, daya beli konsumen terhadap baby buncis terbilang tinggi dan stabil sehingga dapat menjadi peluang bagi usaha Baby French Farmer Group untuk meningkatkan penjualan dan melakukan pengembangan bisnis.

2. Kesempatan memperluas pasar internasional melalui kegiatan ekspor

Cukup banyak bisnis onfarm yang khawatir dengan adanya kegiatan ekspor dan perdagangan bebas yang ada di Indonesia. Sebab dianggap sebagai ancaman di mana akan ada lebih banyak pesaing sesama petani yang berasal dari luar Indonesia. Berbeda dengan kebanyak bisnis onfarm yang lain, usaha Baby French Farmer Group menganggap hal ini sebagai tantangan sekaligus peluang besar untuk melebarkan sayapnya di pasar internasional. Usaha Baby French Farmer Group bahkan semakin terpacu untuk mencari mitra bisnis dari perusahaan ekspor di negara-negara ASEAN hingga Hongkong. Saat ini usaha Baby French Farmer Group sedang mengupayakan untuk membuka kerja sama dengan mitra bisnis di Hongkong di mana saat ini sedang dalam proses pematangan rencana bisnis. Kesempatan ini akan dimanfaatkan dengan sebaik mungkin oleh usaha Baby French Farmer Group mengingat kualitas tanaman baby buncis yang tinggi akan meningkatkan kepercayaan diri bagi perusahaan untuk dapat bersaing dengan produk sayuran dari luar Indonesia.

3. Keadaan geografis lahan pertanian di Bandung Barat

Lahan pertanian di kawasan Bandung Barat terbilang sangat baik mengingat kawasan ini merupakan salah satu sentra budi daya hortikultura di Jawa Barat. Iklim dan kondisi tanam serta ketersediaan air yang 
baik tentunya sangat mendukung kegiatan pertanian termasuk budi daya hortikultura. Terletak di area lereng pegunungan dengan kandungan tanah yang baik turut membantu proses budi daya tanaman baby buncis pada usaha Baby French Farmer Group menjadi sangat produktif. Curah hujan yang cukup juga turut berperan dalam proses penanaman tanaman baby buncis. Berada cukup jauh dari pusat kota menjadikan tanaman baby buncis yang ditanam oleh usaha Baby French Farmer Group bebas polusi dan zat-zat kimia yang dapat membahayakan konsumen.

4. Dinas Pertanian dan Perguruan Tinggi mengakomodasi dan menjadi fasilitator

Usaha Baby French Farmer Group sejauh ini telah melakukan hubungan kerja sama dengan berbagai pihak termasuk Dinas Pertanian hingga Perguruan Tinggi. Hal ini menunjukkan bahwa usaha Baby French Farmer Group telah membuat lingkungan sekitar yang ada notice akan keberadaan usaha ini sehingga bantuan dapat sampai ke tangan petani. Dinas Pertanian memberikan bantuan langsung berupa subsidi pupuk yang dapat digunakan oleh para petani pada usaha Baby French Farmer Group. Di samping itu juga bantuan pemberian informasi terbaru seputar dunia pertanian termasuk di dalamnya pelatihan untuk meningkatkan kemampuan dan pengetahuan petani. Perguruan Tinggi yang bekerjasama dengan usaha ini adalah Universitas Padjajaran, Bandung. Mereka telah menjadikan Gapoktan Wargi Panggupay sebagai objek program pengabdian masyarakat dengan membentuk pogram Value Chain Control (VCC). Kedua hubungan ini memberikan dampak positif bagi produktivitas petani baby buncis pada usaha Baby French Farmer Group.

5. Perkembangan pesat teknologi paska panen Berbekal kemampuan alami yang didapatkan oleh para petani secara otodidak dan turunmenurun dalam melakukan budi daya baby buncis sehingga mampu membawa perusahaan berada pada pasar ekspor. Ditambah lagi informasi dan pengetahuan petani yang senentiasa berkembang berkat pelatihan dari pemerintah. Selain itu kemauan dari para petani untuk berkembang menjadi lebih baik lagi untuk memperbaiki kualitas budi daya tanaman baby buncis. Perkembangan teknik budi daya di dalamnya termasuk pemanfaatan lahan dan pemanfaatan teknologi produksi hingga metode-metode yang dibutuhkan pada proses budi daya seperti metode penjadwalan tanam, metode pengolahan lahan, dan metode pengaturan tenaga kerja. Apabila metode di atas dapat dioptimalkan dengan baik oleh petani pada usaha Baby French Farmer Group, maka diharapkan akan berpengaruh positif terhadap penjualan dan produktivitas petani usaha Baby French Farmer Group.

6. Banyak perusahaan yang bersedia untuk bermitra

Menurut keterangan yang diberikan oleh pemilik usaha Baby French Farmer Group, banyak perusahaan eksportir yang bersedia untuk dijadikan mitra bisnis. Namun, untuk saat ini belum terjadi penambahan jumlah mitra bisnis mengingat kemampuan petani dalam memenuhi permintaan perusahaan eksportir belum maksimal. Dengan adanya manajemen yang baik diharapkan perusahaan mampu mengakomodasi permintaan perusahaan eksportir. Permintaan ekspor dari negara-negara di ASEAN juga turut menjadi daya tarik bagi perusahaan ekspor untuk memperbesar skala usahanya. Dengan demikian perusahaan eksportir akan membutuhkan produsen baby buncis dalam jumlah yang lebih besar. Peluang inilah yang kini menarik perhatian petani usaha Baby French Farmer Group untuk terus melakukan budi daya dengan memperhatikan kualitas baby buncis yang mereka tanam.

\section{Faktor Ancaman Eksternal}

1. Kebutuhan memperoleh tenaga kerja harian Setiap harinya para petani pada usaha Baby French Farmer Group memerlukan tenaga kerja harian untuk membantu proses pemetikan hingga kegiatan lainnya paska panen. 
Petani rata-rata membutuhkan banyak tenaga kerja setiap harinya untuk setiap satu hektare lahan pertanian. Terbatasnya jumlah ketersediaan tenaga kerja di Desa Suntenjaya menjadi ancaman bagi keberlangsungan usaha Baby French Farmer Group. Karena dengan jumlah tenaga kerja yang tidak mencukupi maka akan memungkinkan banyak baby buncis yang terlewat untuk dipanen. Akibatnya baby buncis akan tumbuh lebih besar dari SOP yang ditentukan sehingga tidak dapat dijual ke perusahaan eksportir. Banyak masyarakat di Desa Suntenjaya yang memutuskan untuk beralih pekerjaan ke sektor lain menjadi salah satu penyebab terbatasnya ketersediaan jumlah tenaga kerja di desa itu. Padahal apabila kebutuhan akan tenaga kerja dapat dipenuhi maka aktivitas budi daya akan menjadi lebih optimal dan berpengaruh positif pada produktivitas usaha Baby French Farmer Group.

2. Subsidi pemerintah yang tidak optimal dan tidak tepat sasaran

Pemerintah memang memberikan bantuan dalam bentuk subsidi pupuk ke para petani di Indonesia termasuk para petani usaha Baby French Farmer Group. Akan tetapi hal ini malah menjadi ancaman tersendiri bagi usaha Baby French Farmer Group. Menurut penuturan pemilik dianggap tidak tepat sasaran sehingga tidak membantu petani secara optimal. Pupuk yang diterima oleh petani merupakan jenis kimia, di mana usaha Baby French Farmer Group saat ini menggunakan pupuk organik yang bebas residu. Dengan demikian pupuk yang diberikan oleh pemerintah tidak dapat digunakan para petani untuk membudidayakan tanaman baby buncis. Ditambah lagi petani merasa dengan adanya bantuan ini tidak berdampak signifikan secara keuangan bagi mereka. Sebab harga yang diterima tetap terbilang mahal, di mana menurut para petani yang merasakan keuntungan terbesar berada di tingkat distributor pupuk. Hal ini membuat subsidi pemerintah menjadi ancaman bagi usaha Baby French Farmer Group.
3. Keterbatasan pemenuhan kebutuhan teknologi paska panen

Kegiatan budi daya yang dilakukan oleh para petani usaha Baby French Farmer Group, periode paska panen memiliki peran yang penting. Sebab akan menentukan berjalan tidaknya kegiatan tata niaga pada usaha Baby French Farmer Group. Saat ini para petani masih memiliki kendala dalam mengelola hasil panennya. Tanaman baby buncis yang diproduksi hanya disalurkan ke perusahaan eksportir dan selebihnya dijual ke pasar tradisional dengan harga yang tidak terlalu tinggi. Hal ini terjadi karena para petani yang ada di Baby French Farmer Group belum memiliki teknologi untuk mengolah atau memberikan nilai tambah pada tanaman baby buncis sebagai upaya perpanjangan umur tanaman baby buncis yang dihasilkan pada hari itu juga oleh petani.

4. Keberadaan kompetitor

Besar atau kecil, sedikit atau banyaknya kompetitor yang berada pada suatu lingkungan bisnis, namun tetap akan memberikan ancaman terhadap suatu usaha. Karena perusahaan harus mampu bersaing dan mengungguli kompetitor lain. Selain itu harus mampu memenangkan perusahaan eksportir yang memberikan keuntungan terbaik dan nilai kemitraan yang paling menjanjikan kesejahteraan terbaik bagi petani usaha Baby French Farmer Group. Fakta bahwa perusahaan eksportir yang melakukan kerja sama dengan usaha Baby French Farmer Group memiliki banyak sumber produsen tanaman baby buncis lain di samping usaha Baby French Farmer Group. Hal ini menunjukkan bahwa terdapat banyak kompetitor bisnis yang memproduksi tanaman baby buncis, sehingga menjadi ancaman bagi usaha Baby French Farmer Group.

5. Pemutusan hubungan kerja oleh petani Di dalam usaha Baby French Farmer Group terdapat sebuah Gapoktan bernama Gapoktan Wargi Panggupay yang terdiri atas enam Poktan. Sejak awal berdirinya usaha Baby French Farmer Group memiliki lebih 
dari enam Poktan yang berada di bawah naungan Gapoktan. Namun kini berkurang akibat pemutusan hubungan kerja oleh pe_ tani. Petani-petani ini memutuskan untuk keluar dari usaha Baby French Farmer Group karena merasa sudah memiliki ilmu yang banyak, baik pada aspek budi daya maupun aspek pemasaran. Mereka memutuskan untuk membuat usaha sendiri dan meninggalkan usaha Baby French Farmer Group sebagai tempat mencari ilmu.

\section{Analisis Matriks IFAS dan EFAS}

Analisis Matriks IFAS dan EFAS/Matriks IFE dan EFE akan memberikan gambaran mengenai lingkungan internal dan eksternal bisnis atau perusahaan. Hal ini digunakan untuk mengevaluasi semua faktor-faktor yang ada, baik yang berasal dari dalam sendiri maupun dari lingkungan luar.

\section{Analisis Matriks IFAS}

Matriks IFE (Internal Factors Evaluation) atau Matriks IFAS digunakan untuk mengevaluasi faktor-faktor internal perusahaan berkaitan dengan kekuatan dan kelemahan. Berdasarkan analisis terhadap identifikasi faktor internal bisnis baby buncis kenya Kelompok Tani "Baby French Farmer Group", maka diperoleh 13 faktor kunci sukses internal yang terdiri dari delapan kekuatan dan lima kelemahan internal.

Faktor kunci berupa kekuatan dan kelemahan tersebut diberikan rating/peringkat dan bobot yang diperoleh dari hasil perhitungan rata-rata responden terlebih dahulu. Kemudian skor akan diperoleh dengan cara mengalikan hasil bobot dengan hasil rating/peringkat. Pemberian bobot dan peringkat dilakukan oleh empat responden pengambil keputusan dari internal Kelompok Tani "Baby French Farmer Group", yaitu pemimpin usaha, bagian administrasi dan kesekertariatan serta dua orang petani yang berpengaruh.

Berdasarkan hasil wawancara dengan keempat responden dan perhitungan yang dilakukan, maka diketahui kekuatan yang dimiliki oleh Kelompok Tani "Baby French Farmer Group”. Yaitu (1) koordinasi yang baik dari Ketua Gapoktan selaku pimpinan dengan anggota, (2) kecepatan proses pengambilan keputusan, (3) kestabilan dan profitabilitas harga jual baby buncis, (4) lokasi usaha yang strategis, (5) optimalisasi penggunaan lahan pertanian, (6) ketersediaan sarana produksi, (7) kontrol rantai pasok yang baik, dan (8) kemerataan informasi dalam struktur organisasi.

Sedangkan faktor kelemahan yang dimiliki Kelompok Tani "Baby French Farmer Group" yaitu (1) keterbatasan upaya mencapaikegiatan promosi yang efektif dan efisien, (2) penanganan produk reject yang belum optimal, (3) keterbatasan menemukan sumber keuangan yang stabil dan terpercaya, (4) arus pembayaran yang tersendat, dan (5) lahan pertanian yang terbatas.

Adapun hasil analisis terhadap faktor internal Kelompok Tani "Baby French Farmer Group" sebagaimana tampak pada tabel berikut :

\begin{tabular}{|c|c|c|c|c|}
\hline \multicolumn{5}{|c|}{ Tabel 3.1. Matriks IFAS } \\
\hline \multirow{2}{*}{ No. } & \multirow{2}{*}{ Faktor Internal } & \multirow{2}{*}{ Bobot (a) } & \multirow{2}{*}{ Rating (b) } & Nilai Tertimbang $\{c\}$ \\
\hline & & & & $c=\mathbf{a} \times \mathbf{b}$ \\
\hline \multicolumn{5}{|c|}{ Kekuatan (Strengths) } \\
\hline 1. & $\begin{array}{l}\text { Koordinasi yang baik dari Ketua } \\
\text { Gapoktan selaku pimpinan dengan } \\
\text { anggota }\end{array}$ & 0,078651685 & 3,5 & 0,275280898 \\
\hline 2. & $\begin{array}{l}\text { Kecepatan proses pengambilan } \\
\text { keputusan }\end{array}$ & 0,073033708 & 3,25 & 0,237359551 \\
\hline 3. & $\begin{array}{l}\text { Kestabilan dan profitabilitas harga jual } \\
\text { baby buncis }\end{array}$ & 0,078651685 & 3,5 & 0,275280898 \\
\hline 4. & Lokasi usaha yang strategis & 0,06741573 & 3 & 0,20224719 \\
\hline 5. & $\begin{array}{l}\text { Optimalisasi penggunaan lahan } \\
\text { pertanian }\end{array}$ & 0,073033708 & 3,25 & 0,237359551 \\
\hline 6. & Ketersediaan sarana produksi & 0,078651685 & 3,5 & 0,275280898 \\
\hline 7. & Kontrol rantai pasok yang baik & 0,073033708 & 3,25 & 0,23735955 I \\
\hline 8. & $\begin{array}{l}\text { Kemerataan informasi dalam struktur } \\
\text { organisasi }\end{array}$ & 0,073033708 & 3,25 & 0,237359551 \\
\hline \multicolumn{4}{|c|}{ Total } & 1,977528087 \\
\hline \multicolumn{5}{|c|}{ Kelemahan (Weaknesses) } \\
\hline 9. & $\begin{array}{l}\text { Keterbatasan upaya mencapai kegiatan } \\
\text { promosi yang efcktif dan efisien }\end{array}$ & 0,073033708 & 1,5 & 0,109550562 \\
\hline 10. & $\begin{array}{l}\text { Penanganan produk reject yang belum } \\
\text { optimal }\end{array}$ & 0,08988764 & 1 & 0,08988764 \\
\hline 11. & $\begin{array}{l}\text { Keterbatasan menemukan sumber } \\
\text { keuangan yang stabil dan terpercaya }\end{array}$ & 0,078651685 & 1,5 & 0,117977528 \\
\hline 12. & Arus pembayaran yang tersendat & 0,084269663 & 1,25 & 0,105337079 \\
\hline 13. & Lahan pertanian yang terbatas & 0,078651685 & $\frac{1,25}{1,5}$ & 0,117977528 \\
\hline \multicolumn{4}{|c|}{ Total } & 0,540730336 \\
\hline \multicolumn{4}{|c|}{ Total Kekuatan dan Kelemahan } & 2,518258422 \\
\hline \multicolumn{5}{|c|}{ Sumber : Data Primer, diolah } \\
\hline
\end{tabular}

Adapun hasil dari pemberian bobot dan rating/peringkat yaitu skor IFAS seperti terlihat pada Tabel 3.1 di atas menunjukkan perhitungan Matriks IFAS dengan skor faktor kunci internal yaitu sebesar 2,518258422. Hal ini mengindikasikan bahwa usaha Kelompok Tani "Baby French Farmer Group” memiliki kondisi internal perusahaan yang bersifat average atau rata-rata karena skor faktor kunci internal berada di antara $2.0-2.99$.

Hasil analisis Matriks IFAS untuk elemen 
kekuatan memperoleh skor sebesar 1,977528087, sedangkan untuk elemen kelemahan memperoleh skor sebesar 0,540730336. Nilai total skor kekuatan yang lebih besar dibandingkan kelemahan menunjukkan bahwa dalam mengembangkan usahanya, Kelompok Tani "Baby French Farmer Group" mampu memanfaatkan kekuatan internalnya dan mampu mengatasi kelemahan yang ada.

Selanjutnya dapat pula dilihat pada tabel tersebut bahwa kekuatan utama yang dimiliki usaha Kelompok Tani "Baby French Farmer Group" adalah pada koordinasi yang baik dari Ketua Gapoktan selaku pimpinan dengan anggota, kestabilan, dan profitabilitas harga jual baby buncis serta ketersediaan sarana produksi dengan skor 0,275280898 . Sedangkan kelemahan utama pada usaha Kelompok Tani "Baby French Farmer Group" adalah pada aspek keterbatasan menemukan sumber keuangan yang stabil dan terpercaya serta lahan pertanian yang terbatas dengan skor 0,117977528 .

\section{Analisis Matriks EFAS}

Matriks EFE (External Factors Evaluation) atau Matriks EFAS digunakan untuk mengevaluasi faktor-faktor eksternal perusahaan berkaitan dengan peluang dan ancaman. Berdasarkan analisis terhadap identifikasi faktor eksternal bisnis baby buncis kenya Kelompok Tani "Baby French Farmer Group”, maka diperoleh 11 faktor kunci sukses eksternal yang terdiri dari enam peluang dan lima ancaman eksternal.

Faktor kunci berupa peluang dan ancaman tersebut diberi rating/peringkat dan bobot yang diperoleh dari hasil perhitungan rata-rata responden terlebih dahulu. Kemudian skor akan diperoleh dengan cara mengalikan hasil bobot dengan hasil rating/peringkat. Pemberian bobot dan rating/peringkat dilakukan oleh empat orang responden pengambil keputusan dari internal usaha Kelompok Tani "Baby French Farmer Group" yaitu pemimpin usaha, bagian administrasi dan kesekertariatan serta dua orang petani yang berpengaruh.

Berdasarkan hasil wawancara dengan keempat responden dan perhitungan yang dilakukan, maka tampak peluang yang dimiliki oleh usaha
Kelompok Tani "Baby French Farmer Group". Yaitu (1) permintaan baby buncis oleh konsumen yang tinggi, (2) kesempatan memperluas pasar internasional melalui kegiatan ekspor, (3) keadaan geografis lahan pertanian di Bandung Barat, (4) Dinas Pertanian dan Perguruan Tinggi mengakomodasi dan menjadi fasilitator, (5) perkembangan pesat teknologi paska panen, dan (6) banyaknya perusahaan yang bersedia untuk bermitra.

Sedangkan faktor ancaman yang dimiliki oleh usaha Kelompok Tani "Baby French Farmer Group”, yaitu (1) kebutuhan memperoleh tenaga kerja harian, (2) subsidi pemerintah yang tidak optimal dan tidak tepat sasaran, (3) keterbatasan pemenuhan kebutuhan teknologi paska panen, (4) keberadaan kompetitor, dan (5) pemutusan hubungan kerja oleh petani.

Adapun hasil analisis terhadap faktor eksternal Kelompok Tani "Baby French Farmer Group" sebagaimana tampak pada tabel berikut :

\begin{tabular}{|c|c|c|c|c|}
\hline \multicolumn{5}{|c|}{ Tabel 3.2. Matriks EFAS } \\
\hline \multirow{2}{*}{ No. } & \multirow{2}{*}{ Faktor Eksternal } & \multirow{2}{*}{ Bobot (a) } & \multirow{2}{*}{ Rating (b) } & Nilai Tertimbang $\{c\}$ \\
\hline & & & & $c=a \times b$ \\
\hline \multicolumn{5}{|c|}{ Peluang (Opportunities) } \\
\hline 1. & $\begin{array}{l}\text { Permintaan baby buncis oleh konsumen } \\
\text { yang tinggi }\end{array}$ & 0,101265823 & 4 & 0,405063292 \\
\hline 2. & $\begin{array}{l}\text { Kesempatan memperluas pasar } \\
\text { interrasional melalui kegiatan ekspor }\end{array}$ & 0,082278481 & 3 & 0,246835443 \\
\hline 3. & $\begin{array}{l}\text { Keadaan geografis lahan pertanian di } \\
\text { Bandung Barat }\end{array}$ & 0,094936709 & 3,5 & 0,332278482 \\
\hline 4. & \begin{tabular}{|l} 
Dinas dan Perguruan Tinggi \\
mengakomodasi dan menjadi fasilitator
\end{tabular} & 0,088607595 & 3,5 & 0,310126583 \\
\hline 5. & $\begin{array}{l}\text { Perkembangan pesat teknologi paska } \\
\text { panen }\end{array}$ & 0,088607595 & 2,5 & 0,221518988 \\
\hline 6. & $\begin{array}{l}\text { Banyak perusahaan yang bersedia untuk } \\
\text { bermitra }\end{array}$ & 0,101265823 & 3 & 0,303797469 \\
\hline \multicolumn{4}{|c|}{ Total } & 1,819620256 \\
\hline \multicolumn{5}{|c|}{ Ancaman (Threats) } \\
\hline 7. & $\begin{array}{l}\text { Kebutuhan memeroleh tenaga kerja } \\
\text { harian }\end{array}$ & 0,088607595 & 3,25 & 0,287974684 \\
\hline & $\begin{array}{l}\text { Subsidi pemerintah yang tidak optimal } \\
\text { dan tidak tepat sasaran }\end{array}$ & 0,088607595 & 2,75 & 0,243670886 \\
\hline 9. & $\begin{array}{l}\text { Keterbatasan pemenuhan kebutuhan } \\
\text { teknologi paska panen }\end{array}$ & 0,082278481 & 2,5 & 0,205696203 \\
\hline 10. & Keberadaan kompetitor & 0,088607595 & 3 & 0,265822785 \\
\hline 11. & Pemutusan hubungan kerja olch petani & 0,094936709 & 3 & 0,284810127 \\
\hline \multicolumn{4}{|c|}{ Total } & 1,287974685 \\
\hline \multicolumn{4}{|c|}{ Total Peluang dan Ancaman } & 3,107594941 \\
\hline \multicolumn{5}{|c|}{ Sumber : Data Primer, diolah } \\
\hline
\end{tabular}

Hasil dari pemberian bobot dan rating/peringkat yaitu skor EFAS seperti terlihat pada Tabel 3.2 di atas menunjukkan skor faktor kunci eksternal sebesar 3,107594941. Hal ini mengindikasikan bahwa usaha Kelompok Tani "Baby French Farmer Group" memiliki posisi eksternal yang baik dan merespon kuat terhadap peluang dan ancaman yang mempengaruhi perusahaan. Kondisi perusahaan berada pada posisi yang 
tinggi karena skor faktor kunci internal berada di antara 3.0 - 4.0.

Selanjutnya hasil analisis Matriks EFAS untuk elemen peluang memperoleh skor sebesar 1,819620256, sedangkan untuk elemen ancaman memperoleh skor sebesar 1,287974685. Nilai total skor peluang yang lebih besar dibandingkan ancaman menunjukkan bahwa usaha Kelompok Tani "Baby French Farmer Group" merespon tinggi peluang yang ada dan merespon rendah ancaman yang muncul.

Dapat dilihat pada tabel tersebut bahwa peluang utama yang dimiliki Kelompok Tani "Baby French Farmer Group" adalah pada daya beli konsumen baby buncis yang tinggi dengan skor 0,405063292. Sedangkan ancaman utama pada usaha Kelompok Tani "Baby French Farmer Group" adalah pada kebutuhan memperoleh tenaga kerja harian dengan skor 0,287974684 dan pemutusan hubungan kerja oleh petani dengan skor 0,284810127 .

\section{Analisis Matriks IE (Internal - Eksternal)}

Adapun Matriks IE didasarkan pada dua dimensi kecil yaitu skor bobot IFAS pada sumbu $\mathrm{x}$ dan skor bobot EFAS pada sumbu y. Skor bobot total yang diperoleh dari divisi-divisi tersebut memungkinkan susunan Matriks IE pada tingkat perusahaan.

Oleh karena itu, berdasarkan dari analisis Matriks IFAS terhadap faktor lingkungan internal di mana menghasilkan total skor sebesar 2,518258422, yaitu berada di atas rata-rata nilai 2,50. Hal ini berarti posisi dari pada faktor internal sangat kuat. Dengan demikian perusahaan dapat memanfaatkan faktor kekuatan untuk mengatasi faktor kelemahan yang ada di dalam perusahaan.

Sementara itu berdasarkan analisis Matriks EFAS terhadap faktor lingkungan eksternal, di mana menghasilkan total skor sebesar 3,107594941 yaitu berada pada posisi yang tinggi. Hal ini menunjukkan bahwa posisi faktor eksternalnya yang sangat kuat, sehingga perusahaan dapat memanfaatkan faktor peluang untuk mengatasi ancaman yang mungkin akan muncul terhadap perusahaan.

\section{Pembahasan}

Matriks Internal-Eksternal (IE) Kelompok Tani "Baby French Farmer Group"

Matriks IE digunakan untuk menunjukan posisi perusahaan pada kuadran sembilan sel, di mana posisi tersebut ditentukan oleh titik potong yang dihasilkan oleh koordinat sumbu $\mathrm{x}$ yang merepresentasikan range total nilai tertimbang dari IFE dan koordinat sumbu y yang merepresentasikan range total nilai tertimbang dari EFE.

Berdasarkan analisis yang telah dilakukan pada lingkungan internal dan eksternal usaha Kelompok Tani “Baby French Farmer Group” pada tahap input maka dihasilkan kekuatan, kelemahan, peluang, dan ancaman. Hasil analisis tersebut kemudian dipadukan untuk mengembangkan Matriks IE dan menghasilkan alternatif strategi yang dapat diterapkan pada usaha Kelompok Tani "Baby French Farmer Group".

Adapun hasil analisis tersebut sebagaimana tampak pada gambar berikut ini :

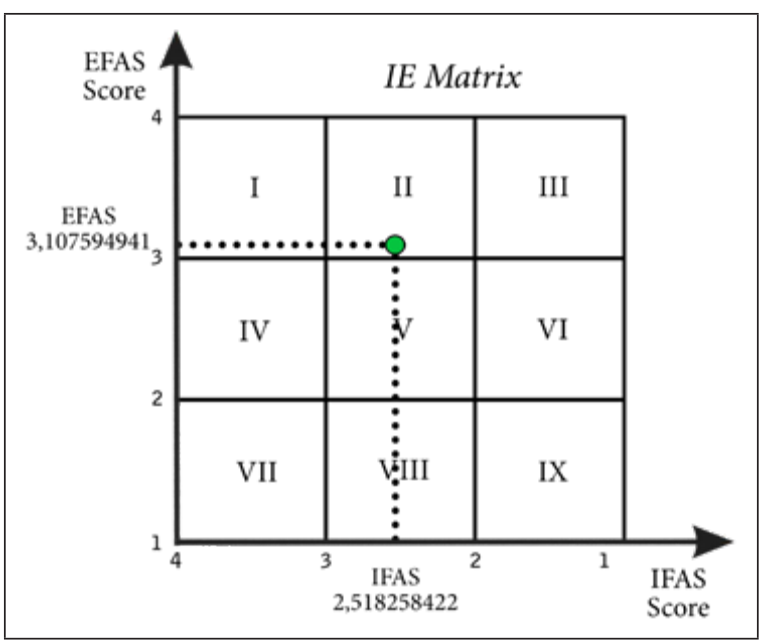

Gambar 1. Posisi Kelompok Tani Baby French Farmer Group

Berdasarkan hasil analisis dengan menggunakan Matriks IE, usaha Kelompok Tani "Baby French Farmer Group" sebagaimana pada gambar di atas terletak pada Kuadran II. Dengan demikian dapat diketahui bahwa strategi yang sesuai bagi Kelompok Tani "Baby French Farmer Group” adalah strategi yang ditunjukkan sebagaimana pada Sel yang ada di Kuadran II. Sel ini merupakan kondisi Tumbuh dan Membangun yang meliputi Sel I, II, dan IV. Adapun strategi pertumbuhan yang dilakukan adalah dengan 
konsentrasi melalui integrasi horisontal.

Dengan demikian alternatif strategi yang terbaik adalah dengan melakukan strategi growth and build. Strategi intensif yang dapat dilakukan adalah strategi penetrasi pasar, pengembangan pasar, dan pengembangan produk. Sementara strategi integratif dengan melakukan strategi integrasi ke depan, integrasi ke belakang, dan integrasi horisontal.

Perusahaan yang berada pada Sel I, II, dan IV berusaha tumbuh dan membangun kondisi yang sudah diperoleh. Hal-hal yang perlu dilakukan adalah penetrasi pasar, pengembangan pasar, dan pengembangan produk. Tumbuh dan Membangun (Growth and Build). Tumbuh dan Membangun $=$ Penetrasi Pasar, Pengembangan Pasar, dan Pengembangan Produk serta Integrasi ke Depan, Integrasi ke Belakang, dan Integrasi Horisontal.

Strategi pertumbuhan melalui integrasi horisontal seperti yang dikemukakan oleh Wheelen \& Hunger (2012), dari sisi internal hendaknya segmen pasar diperluas menjadi lebih besar. Sedangkan dari sisi eksternal perusahaan dapat melakukan akuisisi atau joint venture dengan perusahaan pada industri yang sama, dengan didukung oleh strategi dari Analisis SWOT.

\section{SIMPULAN}

Berdasarkan hasil penelitian dan pembahasan yang sudah dilakukan, dapat disimpulkan bahwa Kelompok Tani "Baby French Farmer Group", sesuai dengan analisis kelayakan bisnis dapat dikatakan layak. Sesuai dengan hasil penelitian, dari sisi insternal kekuatan Kelompok Tani "Baby French Farmer Group" lebih besar dibandingkan dengan kelemahannya. Kemudian dari sisi eksternal peluang lebih besar dibandingkan dengan ancaman. Sehingga strrategi yang sesuai adalah strategi S-O, yakni menggunakan strategi yang memanfaatkan peluang yang ada dengan mendayagunakan kekuatan yang dimiliki.

Apabila dilihat dari hasil perhitungan Matriks IFAS dan Matriks EFAS yaitu masingmasing 2,518258422 dan 3,107594941, maka perusahaan berada pada Kuadran II, yaitu stra- tegi pertumbuhan dengan konsentrasi melalui integrasi horisontal. Oleh karena itu, jika kondisinya seperti ini, maka yang bisa dilakukan adalah strategi intensif dengan cara penetrasi pasar, pengembangan pasar, dan pengembangan produk. Selanjutnya strategi integratif dengan cara integrasi ke belakang, integrasi ke depan, dan integrasi horizontal.

Strategi pertumbuhan melalui strategi horisontal adalah suatu kegiatan untuk memperluas perusahaan dengan cara membangun di lokasi yang lain serta meningkatkan jenis produk dan jasa. Sesuai Matriks SWOT, posisi Kelompok Tani "Baby French Farmer Group" menunjukkan growth konsentrasi melalui integrasi horisontal di mana posisi ini merupakan kondisi yang bagus. Kekuatan internal bisnis Kelompok Tani "Baby French Farmer Group" menuju pada posisi yang tinggi. Begitu pula dengan daya tarik industri yang berada pada posisi yang tinggi pula.

\section{DAFTAR PUSTAKA}

Assauri, Sofjan. (2011). Manajemen Pemasaran. Jakarta: PT RajaGrafindo Persada.

Assauri, Sofjan. (2008). Manajemen Produksi dan Operasi. Edisi Keempat. Jakarta: Lembaga Fakultas Ekonomi Universitas Indonesia.

David, Fred R. (2011). Manajemen Strategis Konsep, Kasus dan Implementasi terjemahan. Jakarta: PT Gasindo.

Handoko, T Hani. (2011). Manajemen. Edisi Kedua. Yogyakarta: BPFE Yogyakarta Anggota IKAPI.

Hasibuan. (2016). Manajemen Sumber Daya Manusia. Jakarta: Penerbit Haji Masagung.

Ishak, Aulia. (2010). Management Operation. Yogyakarta: Graha Ilmu.

Kuncoro, Mudrajad. (2014). Metode Riset untuk

Bisnis dan Ekonomi. Edisi 4. Jakarta: Penerbit Erlangga.

Kotler, Philip \& Keller, K. L. (2009). Manajemen Pemasaran: Analisis, Perencanaan, Implementasi, dan Kontrol Jilid 1 Edisi 13. Jakarta: Penerbit Erlangga.

Kotler, Philip dan Gary Armstrong. (2009). Manajemen Pemasaran. Edisi Ketigabelas. 
Jakarta: Penerbit Erlangga.

Kotler, Philip dan Kevin Lane Keller. (2009). Manajemen Pemasaran Jilid 1 Edisi Ketigabelas. Jakarta: Penerbit Erlangga.

Kotler, Philip dan Kevin Lane Keller. (2009). Manajemen Pemasaran Jilid 2 Edisi Ketigabelas. Jakarta: Penerbit Erlangga.

Kotler, Philip dan Gary Armstrong. (2012). Prinsip-prinsip Pemasaran Jilid 1 Edisi Ketigabelas. Jakarta: Penerbit Erlangga.

Kotler, Philip dan Gary Armstrong. (2012). Prinsip-prinsip Pemasaran Jilid 2 Edisi Ketigabelas. Jakarta: Penerbit Erlangga.

Laksana, Fajar. (2013). Manajemen Pemasaran. Edisi Pertama. Yogyakarta: Graha Ilmu.

Lovelock \& Wright. (2012). Principle of Services Marketing and Management. Upper Saddle River, New Jersey, USA: Prentice Hall Inc.

Manullang. (2012). Dasar-Dasar Manajemen. Yogyakarta: Gajah Mada University Press.

Martono, Nanang. (2010). Metode Penelitian Kuantitatif: Analisis Isi dan Analisis Data Sekunder. Edisi Revisi 2. Jakarta: Penerbit RajaGrafindo Persada.

Naresh, K. Malhotra. (2010). Riset Pemasaran Pendekatan Terapan. Edisi Keempat Jilid 2. Jakarta: PT Indeks.

Pearce, Jhon A. dan Robinson, Richard, B. (2011). Manajemen Strategi: Formulasi, Implementasi, dan Pengendalian. Jakarta: Salemba Empat.

Raco, J. R. (2010). Metode Penelitian Kuantitatif: jenis, karakteristik, dan keunggulannya. Jakarta: Penerbit Grasindo.

Rangkuti, Freddy. (2009). Analisis SWOT Teknik Membedah Kasus Bisnis Reorientasi Konsep Perencanaan Strategi Untuk Menghadapi Abad 21. Jakarta: PT Gramedia.

Rangkuti, F. (2013). Teknik Membedah Kasus Bisnis Analisis SWOT Cara Perhitungan Bobot, Rating, dan OCAI. Jakarta: PT Gramedia Pustaka Utama.

Rangkuti, F. (2015). Analisis SWOT: Teknik Membedah Kasus Bisnis. Jakarta: Gramedia Pustaka Utama.

Render Berry dan Heizer Jay. (2011). Management Operation. Jakarta: Boston.
Silalahi, Ulber. (2011). Asas-Asas Manajemen. Bandung: PT Refika Aditama. Anggota IKAPI.

Sri Wahyudi, Agustinus. (2013). Manajemen Strategik: pengantar proses berpikir strategik. Jakarta: Penerbit Binarupa Aksara.

Sugiyono. (2010). Metode Penelitian Bisnis (Pendekatan Kuantitatif, Kualitatif, dan $R \ll D)$. Bandung: Alfabeta.

Sugiyono. (2012). Metode Penelitian KualitatifKuantitatif dan R\&D. Bandung: Alfabeta.

Sugiyono. (2012). Metode Penelitian Bisnis. Bandung: Penerbit Alfabeta.

Supranto, J. (2012). Metode Riset. Cetakan 2. Jakarta: Penerbit Rineke Cipta.

Terry, George R. dan Rue, Leslie W. (2012). Dasardasar Manajemen. Jakarta: Bumi Aksara.

Wheelen, T. L. dan Hunger, J . D. (2012), Strategic Management and Business Policy: Toward Global Sustainability. Thirteen Edition, Pearson, United States.

Wijayanto, Dian. (2012). Pengantar Manajemen. Jakarta: PT Gramedia Pustaka Utama Anggota IKAPI.

Internet :

Albert Humphrey, Teknik Analisis SWOT, dikutip dari https://id.wikipedia.org/wiki/Analisis_ SWOT, tanggal 27 Juli 2019. 